\title{
Oncoplastic Breast Surgery after Partial Mastectomy Using Thoracoepigastric Fasciocutaneous Flap
}

부분유방 절제술 우 흥복복 근막피부 피판술을 이용한 유방 종양성형술

\section{Department of Surgery, Clinical Medial Research Institute, Pusan National University, College of Medicine Gil-Hwan Kim, Jee Yeon Lee, Seok Won Lee, Young Tae Bae}

부산대학교 의과대학 김길환, 이지연, 이석원, 배영태

\section{초 록}

목적 : 유방암에 있어 종양성형술은 종양학적 안전성뿐만 아니라 만족할만한 미용학적 결과를 확보할 수 있다. 저자들은 유방의 하부 또는 중심부에 위치하는 유방암에 종양성형술의 한 종류인 흥복벽 근막피부 피판술을 적용하여 유용성을 평가해 보고자 하 였다.

대상 및 방법 : 유방암의 위치가 하부 또는 중심부에 위치하는 환 자 38 명를 대상으로 유방의 부분절제술 및 즉각적 흥복벽 근막피 부 피판술을 시행하였다. 종양의 임상적, 병리학적 인지를 후향 적으로 조사하였으며, 방사선 치료 후의 미용학적 결과를 4단계 로 분류하여 평가하였다.

결과 : 평균 추적관찰 기간은 12.2 개월이었으며, 평균 종양의 크 기는 $1.8 \mathrm{~cm}$ 으로 확인되었다. 절제된 종양의 평균 부피는 67.9 $\mathrm{mm}^{3}$ 였으며, 미용학적 결과상 매우 만족하는 경우가 21(55.3\%) 예, 만족하는 경우가 13 (34.2\%)예로 평가되었다.

결론 : 유방의 하부 또는 중심부에 위치하는 유방암에 있어 유방 의 부분절제술 및 즉각적 흥복벽 근막피부 피판술은 비교적 쉬우 면서도 미용학적으로 우수한 결과를 보이는 유용한 종양성형술 이다.

중심단어 : 유방암, 종양성형술; 흉복벽 근막피부 피판술

\section{책임저자 : 배영태}

602-739, 부산 서구 구덕로 179 부산대학교병원외과

Tel: 051-240-7238 Fax: 051-247-1365 E-mail: bytae@pusan.ac.kr

접수일 : 2012년 4월 19일 게재승인일 : 2012년 6월 21일

\section{서 론}

최근 유방암의 조기 발견이 증가함에 따라 즉각적 유방재건술의 빈도도 높아지고 있다. ${ }^{[1-4]}$ 유방암의 수술과 동시에 유방재건을 시 행하는 것을 “종양성형술(oncoplastic surgery)"이라는 명칭으 로 부르게 되는데, 성공적인 종양성형술을 시행하기 위해서는 몇 가지 문제점이 존재한다. 안전한 절제연을 확보하기 위해서는 광 범위 절제술이 당연히 필요하지만, 필요 이상의 절제를 시행하는 경우 유방의 미용학적 면에서 불이익이 발생할 수 있기 때문이 다. ${ }^{[5]}$ 물론 절제연 양성이 확인된 경우라도 재수술 또는 방사선치 료를 통하여 동일한 예후를 얻을 수 있지만, ${ }^{[6]}$ 결국은 경제적인 부 담과 환자의 정신적 충격이 발생할 수 있다.

종양성형술에 있어 종양의 크기와 위치는 매우 중요한 요소이다. 종양의 크기에 따라서 절제되어야 할 유방의 부피가 달라지기 때 문에 각기 다른 피판술을 적용해야 하며, 유경 피판(pedicle flap) 을 시행하는 경우 종양의 위치에 따라서도 피판을 만드는 해부학 적 위치를 달리 적용해야 한다. 특히, 유방의 상외측이 가장 재건 술을 시행하기 용이한 위치이며, 유방의 내측, 중심부, 그리고 하 방에 위치한 경우 다른 부위에 위치한 경우보다 유방의 변형이 심한 것으로 보고되고 있다. ${ }^{[7]}$

종양의 크기가 유방의 하방에 위치하는 경우에는 치료적 축소 유 방성형술(therapuetic reduction mammoplasty), 흥복벽피판술 (thoracoepigastric flap) 등을 적용할 수 있지만, 유방의 내측에 위치하는 경우에는 피판의 길이에 제한이 있어 유방재건에 어려움 이 발생하는 것으로 보고되고 있다. ${ }^{[8,9]}$ 이러한 경우 대부분의 종양 성형의들은 광배근피판술(latissimus dorsi myocutaneous flap), 회전 피판술(glandular rotation flap) 등을 적용해 왔으나, 저자들은 유방의 하측 뿐만 아니라 중심부 또는 내측에 존재하는 종양에 대해서도 흥복벽 근막피부 피판술(thoracoepigastric 
fasciocutaneous flap)을 시행하여 미용학적으로 만족스러운 결 과를 얻었으며 종양학적으로도 안전성을 확보하였기에 이를 보고 하고자 한다.

\section{대상 및 방법}

\section{1) 연구대상}

2010년 1월부터 2011년 12월까지 부산대학교병원 외과에서 유방 암으로 수술 받은 환자들 중 종양의 크기가 $2 \mathrm{~cm}$ 이하이면서 위 치가 하부 또는 중심부에 있는 38 명을 대상으로 유방 부분절제술 및 즉각적 흥복벽 근막피부 피판술을 적용하였다. 이들의 임상병 리학적 인자들은 병력지와 병리 결과지를 참고로 나이, 신체 질 량 지수(body mass index), 폐경 여부, 종양의 크기, 위치 및 개 수, 수술 전 조직검사 방법, 절제된 유방 부피, 수술시간, 재원기 간, 합병증 등을 조사하였고, 조직학적 인자들은 조직병리 결과 지를 바탕으로 종양의 종류, 에스트로겐/프로게스테론 수용체 (estrogen/progesterone receptor) 존재 여부, c-erbB2 유전자 발현정도, 삼중음성(triple negative), 종양의 림프혈관계 및 신 경주위 침윤 여부 등을 후향적으로 조사하였다.

종양의 특성에 따라 수술 이후 항암치료 또는 방사선 치료를 병 행하였으며, 모든 예에서 방사선 치료 종결 이후 3 개월이 되는 시 점에서 Danoff 등이 ${ }^{[10]}$ 제안한 4단계 유방의 미용학적 평가법을 기준으로 환자와 의사에 의해 미용적 평가가 이루어졌다.

\section{2) 수술방법}

수술 전 유방촬영술, 유방 초음파와 자기공명영상 검사 등을 통 하여 종양의 정확한 위치와 다발성 여부를 먼저 확인한다. 유방 촉진상 종양이 만져지지 않는 경우는 수술 전 외래에서 초음파 유도하에 후크와이어를 종양에 위치시킨다.

후크와이어 또는 만져지는 종양을 중심으로 주위 정상 조직 2 츠 를 포함하여 절제한다. 종양 제거 후 남아있는 유방 조직의 12 방 향에서 조직을 채취하여 절제연 상태를 동결절편 검사상 모두 음 성인 것을 확인한다. 필요에 따라서는 액와부 감시림프절 생검술 또는 액와부 림프절 청소술을 시행한다.

종양의 절제연에 모두 종양 세포가 없음이 확인되면, 유방결손 부위 아래 절개선에서 시작하여 액와부 후방선(posterior axillary line)까지 절개선을 제도한다. 피판의 최대 직경이 최소 한 $8 \mathrm{~cm}$ 가 되도록 유방하연(inframammary line)과 거의 평행 한 복부 절개선을 제도한다. 제도한 절개선을 따라 절개를 넣고 흥복벽 근막 피판을 구득한다.(Figure 1) 이 때 흥복벽 피판은 피

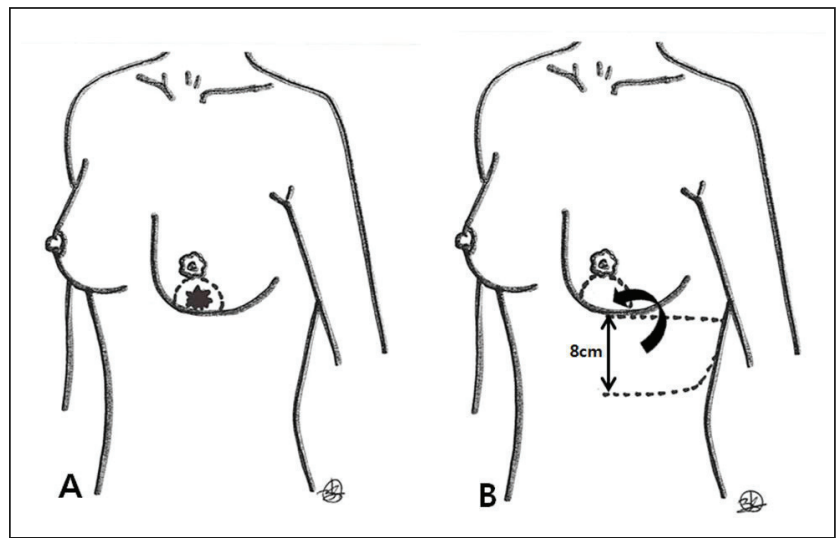

Fig. 1. Preoperative skin markings. (A) The tumor is located on lower site of breast and removed with $2 \mathrm{~cm}$ of safety margins. (B) The diameter of thoracoepigastric flap should be more than $8 \mathrm{~cm}$. The flap will be rotated into the defect of breast.

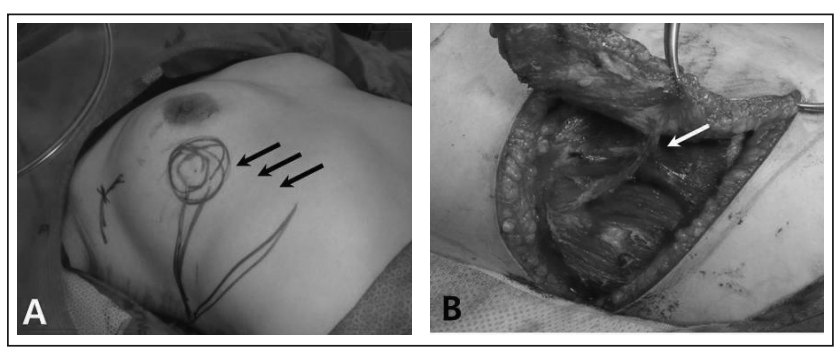

Fig. 2. Design and obtained of thoracoepigastric flap. (A) The perforators of superior epigastric artery(black arrows) are located between medial and lateral margin of rectus muscle. (B) When the thoracoepigastric flap is isolated, a perforator of superior epigastric artery(white arrow) is identified.

부와 피하지방 뿐만 아니라 앞톱니 근막(anterior serratus muscle fascia)을 반드시 포함시켜야 하는데, 이는 근막 내부에 근육으로 연결되는 천공지(perforators)들을 손상이 가지 않게 하기 위함이다.(Figure $2 \mathrm{~A}$ ) 근막을 함께 구득하지 않거나 천공지 를 보존하지 못하면, 상복벽 혈관(superior epigastric vessels) 의 혈류가 원활히 공급되지 못하므로 피판의 부분 소실 또는 지 방 괴사를 야기할 수 있다.

구득한 흥복벽 근막피부 피판을 결손 부위 쪽으로 회전시켜 결손 부위를 피판으로 채우고, 필요에 따라서 피부 절개를 연장한다. 결손 부위의 남은 유방 조직에 피판을 고정시킨 후 피부를 다시 재배치한다. 피판의 포함 정도에 따라 피판의 위, 아래 절개선의 길이에 차이가 발생할 수 있는데, 피부를 $\mathrm{Y}$ 모양의 절개선이 되도 록 교정하면 유방과 피판이 자연스럽게 연결된다. 유방의 피부 
안에 포함되는 피판의 피부는 수술용 가위나 메스를 사용하여 표 피만 얇게 제거하여 혈류공급이 유지되도록 한다. 유방의 모양이 완성되면 수술부위를 지혈한 후 폐쇄 흡인관을 유치하고, 4-0 흡 수성 단일섬유 봉합사로 피부를 연속 봉합한다. (Figure $2 \mathrm{~B}$ )

\section{결 과}

환자들의 평균 연령은 53.2(32 80)세, 평균 신체질량 지수는 $23.1(18.0 \sim 29.3) \mathrm{kg} / \mathrm{m}^{2}$ 이었다. 수술 전 유방초음파에서 측정된 종양의 평균 크기는 $1.4(0.2 \sim 6.0) \mathrm{cm}$ 이었으며, 실제 종양의 평 균 크기는 $1.8(0.2 \sim 7.0) \mathrm{cm}$ 로 큰 차이를 보이지 않았다. 종양의 위치는 유방의 중심부가 16 예로 가장 많았으며, 하외부, 하내부, 하중앙부가 각각 $13,6,3$ 예로 확인되었다. 이들 중 4 예는 다발 성 종양이었으며, 6예는 수술 전 절제 생검을 통하여 유방암이 확진되었다. 절제된 유방의 평균 부피는 $67.9\left(10.6\right.$ 180.9) $\mathrm{mm}^{3}$ 였으며, 실제 유방 부피에 대한 절제된 조직의 백분율은 약 $17.0 \%$ 이었다. 평균 수술 시간은 종양절제술과 성형술을 포함하 여 약 125 분으로 측정되었으며, 평균 재원일수는 6 일이었다. 입 원 기간동안 발생한 단기 합병증으로는 1 예에서만 알러지성 피 부염이 발생하였으며, 이는 보존적 치료로 완치가 가능하였다 (Table 1).

종양의 종류는 침윤성 유관암이 27(71.1\%)예로 가장 많았으며, 상피내암과 점액성 유방암이 각각 9 예와 2 예에서 확진되었다.

Table 1. Clinicopathologic characteristics of the 38 patients who underwent thoracoepigastric fasciocutaneous flap

\begin{tabular}{ll}
\hline Mean age (yrs, range) & $52.2(32-80)$ \\
Mean BMI* (kg/m², range) $_{\text {Mean clinical tumor size (cm, range) }} 23.1(18.0-29.3)$ \\
Mean pathologic tumor size (cm, range) & $1.4(0.2-6)$ \\
Location of tumor (n, \%) & $1.8(0.2 ? 7)$ \\
Lower outer & \\
Lower middle & $13(34.2)$ \\
Lower inner & $3(7.9)$ \\
Central & $6(15.8)$ \\
Cases of multifocality (n, \%) & $16(42.1)$ \\
Preoperative biopsy (n, \%) & $4(10.5)$ \\
Needle biopsy & \\
Excision biopsy & $32(84.2)$ \\
Mean excised breast volume (mm ${ }^{3}$, range) & $6(15.8)$ \\
Mean operative time (min, range) & $67.9(10.6-180.9)$ \\
Mean hospital stay (day, range) & $124.7(80-310)$ \\
Mean follow-up period (mo, range) & $6(4-14)$ \\
Complication ${ }^{\dagger}$ (n, \%) & $12.2(4-31)$ \\
\hline
\end{tabular}

*Body Mass Index; ${ }^{\dagger}$ complication was allergic dermatitis which was resolved with conservative treatment.
에스트로겐 수용체와 프로게스테론 수용체는 각각 33(86.8\%) 예, 27(71.1\%)예에서 양성으로 확인되었으며, c-erbB2 유전자 는 $17(44.7 \%)$ 예에서 양성으로 나타났다. 삼중 음성은 $2(5.3 \%)$ 예에서만 확인되었으며, 종양 세포의 림프혈관계 침윤과 신경주 위 침윤은 각각 $4(10.5 \%)$ 예와 $1(2.6 \%)$ 예에서 나타났다. 종양의 병기는 0 기가 $9(23.7 \%)$ 예, 1 기가 $17(44.7 \%)$ 예, $2 \mathrm{~A}$ 기가 6 (15.8\%)예, $2 \mathrm{~B}$ 기가 $3(7.9 \%)$ 예였으며, $3 \mathrm{~A}$ 기도 2(5.3\%)예가 포 함되어 있었다. (Table 2)

Figure 3과 같이 유방의 수술 전과 방사선 치료 후의 상태를 비 교하여 4단계 미용학적 평가를 시행하였으며, 매우 만족하는 경 우가 20(52.6\%)예, 만족하는 경우와 그저 그렇다고 평가를 내린 경우는 각각 14 예와 4 예였다. (Table 3)

\section{고 찰}

유방암의 조기 발견과 환자들의 유방 재건에 대한 요구도가 높아 짐에 따라 종양성형술은 조기 유방암의 표준치료로 자리잡았다.

Table 2. Histopathologic characteristics of the 38 patients who underwent thoracoepigastric fasciocutaneous flap

\begin{tabular}{|c|c|}
\hline Variables & $n(\%)$ \\
\hline \multicolumn{2}{|l|}{ Histology } \\
\hline Ductal carcinoma in situ & $9(23.6)$ \\
\hline Invasive ductal carcinoma & $27(71.1)$ \\
\hline Mucinous carcinoma & $2(5.3)$ \\
\hline \multicolumn{2}{|l|}{ Estrogen receptor } \\
\hline Positive & $33(86.8)$ \\
\hline Negative & $5(13.2)$ \\
\hline \multicolumn{2}{|l|}{ Progesterone receptor } \\
\hline Positive & $27(71.1)$ \\
\hline Negative & $11(28.9)$ \\
\hline \multicolumn{2}{|l|}{ c-erbB2 gene } \\
\hline Positive & $17(44.7)$ \\
\hline Negative & $21(55.3)$ \\
\hline \multicolumn{2}{|l|}{ Triple negative } \\
\hline Yes & $2(5.3)$ \\
\hline No & $36(94.7)$ \\
\hline \multicolumn{2}{|l|}{ Lymphovascular invasion } \\
\hline Yes & $4(10.5)$ \\
\hline No & $25(65.8)$ \\
\hline \multicolumn{2}{|l|}{ Perineural invasion } \\
\hline Yes & $1(2.6)$ \\
\hline No & $28(73.7)$ \\
\hline \multicolumn{2}{|l|}{ Tumor stage } \\
\hline Stage 0 & $9(23.7)$ \\
\hline Stage I & $17(44.7)$ \\
\hline Stage IIA & $6(15.8)$ \\
\hline Stage IIB & $3(7.9)$ \\
\hline Stage IIIA & $2(5.3)$ \\
\hline
\end{tabular}


Table 3. Cosmetic outcome of the thirty-eight patients who undergone thoracoepigastric fasciocutaneous flap

\begin{tabular}{|c|c|c|c|c|c|}
\hline Cosmetic outcome $(n, \%)$ & Lower outer & Lower middle & Lower inner & Central & Total \\
\hline Excellent & $9(23.7)$ & 2 (5.3) & $1(2.7)$ & $9(23.7)$ & 21 (55.3) \\
\hline Good & $4(10.5)$ & $1(2.7)$ & $2(5.3)$ & $6(15.8)$ & $13(34.2)$ \\
\hline Fair & 0 & 0 & $3(7.9)$ & $1(2.7)$ & $4(10.5)$ \\
\hline Poor & 0 & 0 & 0 & 0 & 0 \\
\hline
\end{tabular}
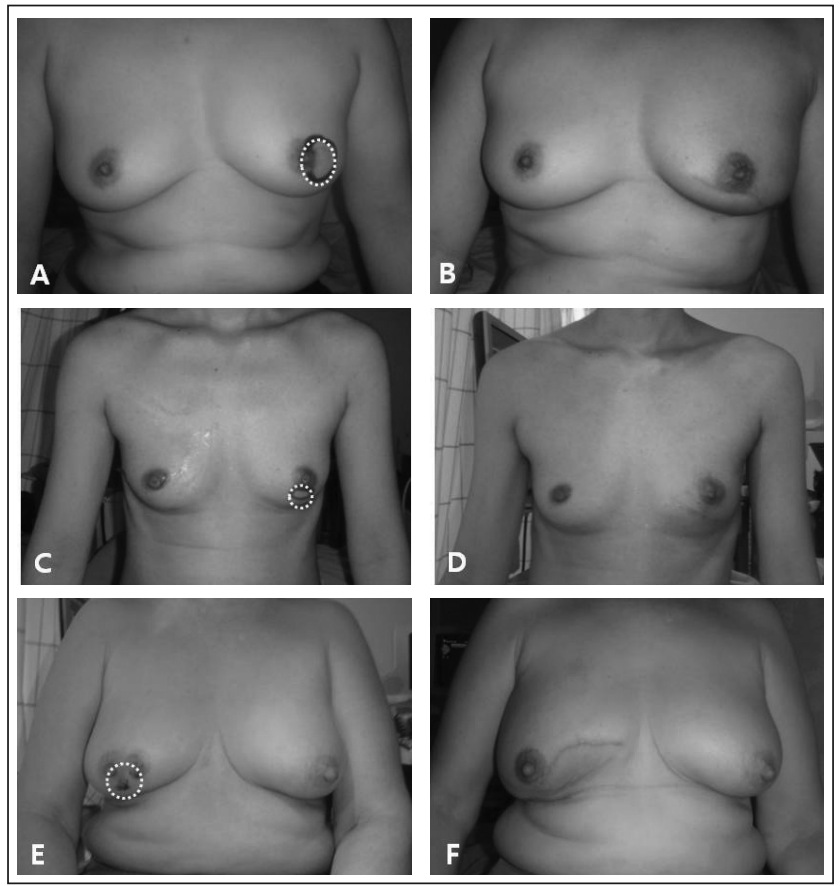

Fig. 3. Preoperative and postoperative views. (A, C, E) The breast cancers are marked with dot circles. (B, D, F) The cosmetic outcomes are evaluated at least 3 months after radiotherapy.

종양성형술이란, 1998년 Audretsch 등에 ${ }^{[11}$ 의해 처음 사용되었던 단어로 유방암의 수술로서 종양학적 안정성을 확보하면서도 유방 변형을 예방하기 위해 유방 재건을 동시에 시행하는 수술 방법을 말한다. 종양성형술은 크게 주변 조직만을 이용하는 조직 이동술 (volume displacement method)과 조직 대체술(volume replacement method)로 나눌 수 있다. 조직 이동술은 주로 국소 피판 또는 주위의 근막피부 피판(fasciocutaneous flap)을 이용하 며, 종양의 위치에 따라 유선 조직의 회전술, 외측 흥벽 전진술 (lateral thoracic wall advanced flap), 흥복벽 근막피부 피판술, 외측 흥배 근막피부 피판술(lateral thoracodorsal fasciocutaneous flap), 유방 고정술(mastopexy), 그리고 축소 유방성형술 (reduction mammoplasty) 등을 적용할 수 있다. 반면에 조직 대 체술은 원거리에 있는 근육이나 근막피부 피판 등으로 조직을 대
체하는 방법으로 유경 피판 또는 유리 피판으로서 필요한 조직의 부피에 따라 광배근, 횡복직근 등을 이용할 수 있다. ${ }^{[12,13]}$ 종양의 크기와 위치는 각각에 따라 다른 술식을 적용해야 하므로 종양 성형술에 있어 가장 중요한 요소라 할 수 있다. ${ }^{[9,14,15]}$ 흥복벽 근막피부 피판술은 비교적 크기가 크지 않으면서 종양이 유방의 하부 또는 중심부에 위치하는 경우에 적절한 술식이다. 저자들의 연구에 포함된 환자들의 임상적 종양 크기는 $1.4 \mathrm{~cm}$, 실제 종양 의 크기는 $1.8 \mathrm{~cm}$ 이었으며, 종양의 위치는 유방의 중심부가 16 예, 하외부가 13 예, 하중부가 3 예, 하내부가 6 예로 확인되었다. 그러나, 위치에 따른 미용학적 평가에는 큰 차이가 없었으며, 흥 복벽 피판술은 유방의 중심부에 종양이 위치한 경우에도 적용할 수 있는 술식임을 알 수 있었다.

유방하수의 정도가 심하면서 종양이 유방의 하부에 위치하는 경 우에는 치료적 유방 축소술도 고려할 수 있지만, ${ }^{[1,69]}$ 양쪽 유방의 균형을 위하여 반대편 유방에도 어느 정도의 축소술을 시행해야 하는 경우가 많다. 저자들은 유방 하수의 정도가 심하지 않거나 환자들이 반대편 유방의 수술을 거부한 경우만을 포함하여 본 술 식을 적용하였으며, 비교적 양호한 미용학적 결과를 얻었다고 볼 수 있다.

흥복벽 근막피부 피판술은 절개선의 길이에 따라 피판의 위치 이 동이 원활하며, 주위에 위험한 혈관이나 구조물이 거의 없기 때 문에 비교적 간단한 술식이다. 그러나, 피판을 구득할 때 반드시 근막을 포함해야 하고 근막을 통과하는 주요 천공지 혈관은 보존 해야 한다. 여러 개의 천공지 혈관들을 모두 보존할 필요는 없지 만, 모든 천공지 혈관들이 손상을 받는 경우 피판의 괴사 또는 지 방 괴사 등이 발생할 수 있기 때문이다.

흥복벽 피판술을 적용시 결손 부위나 유방하수 정도에 따라 유 두-유륜 복합체의 위치가 달라지는 경우가 발생하기도 한다. 주 로 유두-유륜 복합체가 하내측으로 이동하게 되는데, 이는 양측 유두 위치의 불균형을 초래하기도 한다. 이를 보완하기 위하여 반대편 유두의 위치를 기준으로 유두를 이동시켜 주거나 남아있 는 유방 조직을 외측으로 당기면서 피판을 고정하면 훨씬 더 자 
연스러운 유방 모양과 유두 위치를 찾을 수 있다. 이러한 간단한 방법으로라도 유두 위치의 균형을 이룬 환자들에서 미용학적 평 가가 조금 더 높게 나타났던 것으로 보아 번거롭더라도 술자의 경험에 따라 이를 보완해 주는 것이 환자에게 이득을 줄 수 있을 것으로 판단된다.

유방보존술의 미용적 효과는 종양의 크기와 위치 외에도 유방의 크기와 수술 절제 범위 등에 의해서도 달라지게 된다. Clough 등 과 Hoffmann 등은 ${ }^{[13,16]}$ 유방의 절제 부위가 $20 \%$ 이하이면 주변 유선 조직의 이동술에 의한 국소 피판술로 결손부위를 채울 수 있지만, 결손 부위가 20-50\%인 경우에는 유경 피판(pedicled flap)이나 유리 피판(free flap) 등을 포함하는 복합 종양성형술이 필요하다고 언급한 바 있다. 저자들의 경우 전체 유방에 대한 절 제된 조직의 비율은 평균 $17.0 \%$ 정도였으며, 원거리 피판술 없이 국소 피판술의 한 종류인 흥복벽 피판술만으로 비교적 좋은 미용 학적 결과를 얻을 수 있었다.

흥복벽 근막피부 피판술은 이미 Audretsch와 Bae 등 ${ }^{[11,17-20]}$ 여러 종양성형의에 의하여 보고된 바 있는 종양 성형술이다. 저자들 도 혈액 공급이 좋은 상복벽혈관 혈관과 앞톱니 근막을 통과하 는 천공지를 포함시켜야 하는 점을 주의하여 유방의 하부 또는 중심부에 위치하는 유방암에 본 술식을 적용하여 유방의 결손부 위를 재건하였으며, 비교적 우수한 성적을 얻었기에 이를 보고 하는 바이다.

\section{결 론}

흥복벽 근막피부 피판술은 비교적 쉬울 뿐만 아니라 유방 하부에 위치한 종양의 안전한 절제연 확보와 수술 후 결손 부위의 주요 변형 없이 미용학적 결과를 얻을 수 있는 술식으로 매우 유용한 종양성형술의 한 방법이라 할 수 있다.

\section{REFERENCES}

1. Clough KB, Lewis JS, Couturaud B, Fitoussi A, Nos C, Falcou $\mathrm{MC}$. Oncoplastic techniques allow extensive resections for breastconserving therapy of breast carcinomas. Ann Surg 2003;237:26-34.

2. Slavin SA, Love SM, Sadowsky NL. Reconstruction of the radiated partial mastectomy defect with autogenous tissues. Plast Reconstr Surg 1992;90:854-869.

3. Kroll SS, Singletary SE. Repair of partial mastectomy defects. Clin Plast Surg 1998;25:303-310.

4. Chevray PM, Robb GL. Breast reconstruction. In: Hunt KK, Robb GL, Strom EA, Ueno NT, editors. M.D. Anderson Cancer
Care Series Breast Cancer. 2nd ed. New York: Springer Sience, 2008:235-269.

5. Clough KB, Kroll SS, Audretsch W. An approach to the repair of partial mastectomy defects. Plast Reconstr Surg 1999;104:409-420.

6. Jobsen JJ, van der Palen J, Ong F. Effect of external boost volume in breast-conserving therapy on local control with longterm follow-up. Int J Radiat Oncol Biol Phys 2008;71:115-122.

7. Vrieling $C$, Collette $L$, Fourquet $A$, Hoogenraad WJ, Horiot JH, Jager $\mathrm{JJ}$, et al. The influence of patient, tumor and treatment factors on the cosmetic results after breast-conserving therapy in the EORTC 'boost vs. no boost' trial. EORTC Radiotherapy and Breast Cancer Cooperative Groups. Radiother Oncol 2000:55:219-232.

8. Kronowitz SJ, Feledy JA, Hunt KK, Kuerer HM, Youssef A, Koutz $C A$, et al. Determining the optimal approach to breast reconstruction after partial mastectomy. Plast Reconstr Surg 2006;117:1-14

9. Clough KB, Nos C, Salmon RJ, Soussaline M, Durand JC. Conservative treatment of breast cancers by mammaplasty and irradiation: a new approach to lower quadrant tumors. Plast Reconstr Surg 1995;96:363-370.

10. Danoff BF, Goodman RL, Glick JH, Haller DG, Pajak TF. The effect of adjuvant chemotherapy on cosmesis and complications in patients with breast cancer treated by definitive irradiation. Int $\mathrm{J}$ Radiat Oncol Biol Phys 1983;9:1625-1630.

11. Audretsch W. Reconstruction of the partial mastectomy defect: classification and method. In: Spear SL, ed. Surgery of the Breast: Principles and Art. 1th ed. Philadelphia: Lippincott-Raven, 1998;155-196.

12. Losken A, Styblo TM, Carlson GW, Jones GE, Amerson BJ. Management algorithm and outcome evaluation of partial mastectomy defects treated using reduction or mastopexy techniques. Ann Plast Surg 2007;59:235-242.

13. Clough KB, Kaufman GJ, Nos C, Buccimazza I, Sarfati IM. Improving breast cancer surgery: a classification and quadrant per quadrant atlas for oncoplastic surgery. Ann Surg Oncol 2010;17:1375-1391.

14. Clough KB, Cuminet J, Fitoussi A, Nos C, Mosseri V. Cosmetic sequelae after conservative treatment for breast cancer: classification and results of surgical correction. Ann Plast Surg 1998:41:471-481.

15. Noguchi M, Saito $Y$, Mizukami $Y$, Nonomura A, Ohta N, Koyasaki $\mathrm{N}$, et al. Breast deformity, its correction, and assessment of breast conserving surgery. Breast Cancer Res Treat 1991;18:111-118.

16. Hoffmann J, Wallwiener D. Classifying breast cancer surgery: a novel, complexity-based system for oncological, oncoplastic and 
reconstructive procedures, and proof of principle by analysis of 1225 operations in 1166 patients. BMC Cancer 2009;9:108.

17. Bae YT. Oncoplastic Breast Surgery. J Korean Med Assoc 2009;52:981-995.

18. Bohmert $\mathrm{H}$. Experience in breast reconstruction with thoracoepigastric and advancement flaps. Acta Chir Belg 1980;79:105-110.
19. Berrino P, Campora E, Santi P. Postquadrantectomy breast deformities: classification and techniques of surgical correction. Plast Reconstr Surg 1987;79:567-572.

20. Matory WE Jr, Wertheimer M, Fitzgerald TJ, Walton RL, Love S, Matory WE. Aesthetic results following partial mastectomy and radiation therapy. Plast Reconstr Surg 1990;85:739-746. 


\title{
Oncoplastic Breast Surgery after Partial Mastectomy Using Thoracoepigastric Fasciocutaneous Flap
}

\author{
Department of Surgery, Clinical Medial Research Institute, Pusan National University, College of Medicine \\ Gil-Hwan Kim, Jee Yeon Lee, Seok Won Lee, Young Tae Bae
}

\begin{abstract}
Purpose : Not only oncologic safety but also satisfactory cosmetic results can be achieved by oncoplastic breast surgery. Authors applied thorcoepigastirc fasciocutaneous flap as oncoplastic surgery for patient with lower or cental portion of breast cancer, to assess the usefulness of this procedure.

Patients and methods : A total of thirty-eight patients with lower or central portion of breast cancer underwent a partial mastectomy with immediate thorcoepigastirc fasciocutaneous flap reconstruction. The clinicopathologic factors were analyzed retrospectively and the cosmetic outcomes were evaluated based on 4-point scoring system.

Results : The mean follow-up period was 12.2 months and mean tumor size was $1.8 \mathrm{~cm}$. The mean excised breast volume was $67.9 \mathrm{~mm}^{3}$ and the cosmetic result showed excellent in $21(55.3 \%)$ and good in $13(34.2 \%)$.

Conclusion : The partial mastectomy with immediate thoracoepigastric fasciocutaneous flap would be a useful oncoplastic surgery for breast cancers which are located in lower or central portion of the breast.
\end{abstract}

Key Words : breast cancer; oncoplastic surgery; thoracoepigastric fasciocutaneous flap

Correspondence : Young Tae Bae

Received : Ami-dong 1-ga, Seo-gu, Pusan National Univerisity hospital, Busan, Republic of Korea

Tel: +82-51-240-7238 Fax: +82-51-247-1365 E-mail: bytae@pusan.ac.kr

Received : April 19, 2012 Accepted : Jun 21, 2012

*This work was supported by a 2-Year Research Grant of Pusan National University. 